\title{
Polyphenols leaching and seed dormancy in carob (Ceratonia siliqua L.) in relation to hot water treatment
}

\author{
Valeria Cavallaro ${ }^{1} \cdot$ Carmelo Maucieri $^{2} \cdot$ Cristina Patanè $^{1} \cdot$ Giancarlo Fascella $^{3} \cdot$ Alessandra Pellegrino $^{1}$. \\ Antonio C. Barbera ${ }^{4}$
}

Received: 11 July 2020 / Revised: 3 August 2021 / Accepted: 24 September 2021 / Published online: 11 October 2021

(c) The Author(s) 2021

\begin{abstract}
Carob (Ceratonia siliqua L.) is a relevant element of the Mediterranean spontaneous vegetation. Moreover, it is useful in reforestation, and it is currently re-valued for sustainable agriculture in dryland areas. However, the difficulties tied to carob propagation (mainly seed dormancy) hamper its large-scale cultivation. In this paper, the effects of four seed treatments (no treatment [control], soaking at $70{ }^{\circ} \mathrm{C}$ and $90{ }^{\circ} \mathrm{C}$ in water, or in $96 \%$ sulphuric acid) on five carob genotypes germination were studied. As compared to the very low germination of untreated seeds (0-13\% germination), sulphuric acid (93-100\% germination) and $90{ }^{\circ} \mathrm{C}$ water soaking (from 72 to $>90 \%$ germination in four out the five genotypes) were effective in promoting germination. Soaking at $90{ }^{\circ} \mathrm{C}$ resulted in the leaching of a higher amount of total polyphenols from the genotypes seed coat as compared to soaking at $70^{\circ} \mathrm{C}$. A significant correlation $\left(0.75^{* *}\right)$ was ascertained between polyphenol leaching of the different genotypes and germination. These results suggest that dormancy in this species is not primarily associated with seed coat hardness, as it is generally thought, but also with the release of polyphenols. Polyphenols determination of the dormant and the few non-dormant seeds of the different genotypes also seem to confirm this hypothesis since these last showed an almost halved total polyphenols content (on average 17.0) as compared to dormant ones ( $34.8 \mathrm{mg} \mathrm{g}^{-1}$ of seed FW). Further studies may determine the polyphenols involved, but also assess new, easier to carry out, seed treatments. The important role of the galactomannans on seed germination of carob is also discussed. Finally, similar studies may enhance the knowledge of dormancy processes in other Fabaceae species whose germination is positively affected by hot water treatments.
\end{abstract}

Keywords Carob $\cdot$ Seed germination $\cdot$ Dormancy $\cdot$ Polyphenols leaching $\cdot$ Seed treatments

Communicated by M. Horbowicz.

Carmelo Maucieri

carmelo.maucieri@unipd.it

1 Institute of BioEconomy, National Research Council (CNRIBE), Via P. Gaifami 18, 95126 Catania, Italy

2 Department of Agronomy, Food, Natural Resources, Animals and Environment (DAFNAE), Viale dell'Università 16, 35020 Legnaro, PD, Italy

3 Council for Agricultural Research and Economics (CREA), Research Centre for Plant Protection and Certification, S.S. 113 - Km 245.500, 90011 Bagheria, Italy

4 Department of Agriculture, Food and Environment-Di3A, University of Catania, Via Valdisavoia 5, 95123 Catania, Italy

\section{Introduction}

Seed dormancy is commonly considered as the inability of a viable seed to germinate under suitable environmental conditions. In many wild species, it is an important ecological feature, since the scattering of germination overtime permits some species to survive when unfavorable environmental conditions occur, damaging the portion of readily germinable seeds (Baskin and Baskin 2014). In crop species, it may be an undesirable trait to be removed (e.g., Lupinus angustifolius and Glycine max) or to be introduced (e.g., Arachis hypogea to prevent preharvest sprouting) by breeding (Forbes and Wells 1968; Kilen and Hartwig 1978; Rolston 1978).

Dormancy linked to waterproofness of the seed coat (physical dormancy according to Baskin and Baskin 2004) affects several families of angiosperms and many members of the Fabaceae family (Silveira and Fernandes 2006; Gresta 
et al. 2011; Venier et al. 2012; Hosseini et al. 2013; Toscano et al. 2017). Due to the capability to fix nitrogen (N), the Fabaceae species exert an important role within the wild plant community, but also as crops for sustainable agriculture. The comprehension of the dormancy processes associated with their germination is therefore important.

The Fabaceae seed coats are constituted of a single palisade layer (Rolston 1978; Bianco and Kraus 2005) of tightly packed radially elongated sclereids, with heavily and unevenly thickened cell walls. A cuticle and waxy depositions also characterize seed coat surface (Gunes et al. 2013). Other substances (e.g., lignin, callose, lipids, phenolic deposits, cutin, wax, and suberin) impregnating the seed coat has also been reported to contribute to its permeability (Venier et al. 2012). In different studies on some Fabaceae species, physical, mechanical or chemical treatments (Mackay et al. 1995; Silveira and Fernandes 2006) or in some cases ultrasonic treatments (Lahijanian and Nazari 2017; Rifna et al. 2019) were able to overcome dormancy, and seem to demonstrate that this phenomenon is tied to the impermeable seed coat (Gresta et al. 2007; Cavallaro et al. 2016).

Carob (Ceratonia siliqua L.) is a valuable, sclerophyll species of the Fabaceae family, and an important element of the Mediterranean spontaneous flora. In some areas, it is part of the Oleo-Ceratonion alliance of plant communities appearing in the thermo-Mediterranean zone (Brosche 2017). Due to its contribution to the maintenance of soil fertility, carob improves the establishment of other species, and is particularly suitable for the reforestation in the harsh climatic conditions and poor soils of some Mediterranean basin areas (pioneer and productive species). In these marginal areas, as a cultivated species, carob is able to provide environmentally and economically valuable productions: carob bean gum, fodder for ruminants and non-ruminants, sugar syrups, cocoa substitutes, bioethanol, and secondary metabolites (Gubbuk et al. 2010; Mazaheri et al. 2012; Amessis-Ouchemoukh et al. 2017; Benković et al. 2017).

Based on these considerations, in recent years, this species has been revalued for agriculture diversification and fertility restoration in semi-arid areas (Janick and Paull 2008). However, the extension of carob cultivation is hindered by its uneasy propagation either by seed or by cuttings. Similar to other legumes, carob seeds show poor and uneven germination usually attributed to the hard seed coat (i.e. physical dormancy). For this species, seed dormancy is a useful way to establish a persistent seed bank in the soil (Ortiz et al. 1995) and to favour the dispersal by animals and the subsistence after fires frequently occurring in the Mediterranean areas (Piotto and Di Noi 2003). In the past, in cultivated carob, farmers selective pressure addressed mainly to enhance pod size for animal fodder or seed yield for flour extraction but not to improve seed germination. However, even if seed dormancy is useful for species survival, it may represent a technical problem for plant production programs. Previously identified best pre-sowing treatments for increasing carob seeds germination are: acid chemical scarification, hot water soaking, and mechanical scarification (Tsakaldimi and Ganatsas 2001; Piotto and Di Noi 2003; Pérez-García 2009; Gunes et al. 2013).

In a previous work (Cavallaro et al. 2016), carob seed germination of four genotypes harvested in a representative Mediterranean area (Sicily) ranged from 1.3 to $27 \%$. Mechanical (seed piercing) and chemical (sulphuric acid) scarification determined a germination rate exceeding $85 \%$ in all tested genotypes. In the present experiment, to clarify the mechanisms of seed dormancy, the effects of hot water and sulphuric acid soaking on carob seed germination were explored. Polyphenols have been recognized as components of the leguminous seed coat having a good water solubility and capability to inhibit germination in some other species (Kong et al. 2008; Inácio et al. 2013). Therefore, total polyphenols leaching after hot water soaking was examined since this treatment does not determine the piercing (as mechanical scarification), nor the complete removal of all the constituents of the seed coat (as sulphuric acid treatment).

\section{Materials and methods}

\section{Seeds collection}

Mature pods of five different genotypes of carob were collected in situ from trees growing in different Sicilian areas of traditionally carob cultivation. The cultivation areas were characterized by different soil typologies (from loam to sandy soils), altitudes and rains (Tables 1 and 2). After
Table 1 Origin, altitude, soil classification and 1000 seed weight of the collected genotypes

\begin{tabular}{llllll}
\hline Code & Origin & Sicilian province & $\begin{array}{l}\text { Altitude } \\
\text { (m a.s.l.) }\end{array}$ & $\begin{array}{l}\text { Soil classifica- } \\
\text { tion (USDA) }\end{array}$ & $\begin{array}{l}1000 \text { seed } \\
\text { weight (g) }\end{array}$ \\
\hline Sorba & Catania plain & Catania & 36 & Sandy clay & 202.7 \\
Pignato & C.da Pignato (Ispica) & Ragusa & 44 & Loam & 209.2 \\
Margitello & C.da Margitello (Ispica) & Ragusa & 78 & Sandy loam & 215.8 \\
Calamiccio & C.da Calamiccio (Ispica) & Ragusa & 88 & Silt loam & 215.0 \\
TDP & Zisola (Noto) & Siracusa & 110 & Loam & 209.9 \\
\hline
\end{tabular}


Table 2 Minimum, maximum and mean rains over thirty years (1965-1994) period (Cartabellotta et al., 1998)

\begin{tabular}{llll}
\hline Locality & Min & Mean & Max \\
\hline Ispica & 202 & 445 & 693 \\
Noto & 251 & 615 & 1051 \\
Catania & 230 & 685 & 1021 \\
\hline
\end{tabular}

harvest, the seeds were separated from the pods and stored at room temperature in paper bags. The weight of 1000 seeds ranged from 202.7 to $215.8 \mathrm{~g}$ (Table 1).

\section{Experimental factors}

(1) Genotype (5) (Table 1).

(2) Seed treatment (4): (i) no treatment (control); (ii) hot water soaking at $70{ }^{\circ} \mathrm{C}$; (iii) hot water soaking at $90^{\circ} \mathrm{C}$; (iv) soaking in $96 \%$ sulphuric acid solution for $20 \mathrm{~min}$. The optimal duration of the acid treatment was chosen on the basis of our previous trials (Cavallaro et al. 2016).

For the hot soaking treatment, 100 seeds were kept in the water at one of the two temperatures until the temperature of the water dropped to that of the ambient (approximately $20^{\circ} \mathrm{C}$ ). After each treatment, the seeds were placed in $9-\mathrm{cm}$ Petri dishes (three replicates of 30 seeds each) containing a single filter paper moistened with $7 \mathrm{~mL}$ distilled water. Germination temperature was $20^{\circ} \mathrm{C}$.

Germination was assessed when the radicle reached approximately $2 \mathrm{~mm}$ of length, and data were recorded daily. At the end of the experiment (thirty days after the beginning of the germination test), the final germination percentage was calculated.

\section{Total polyphenols content (TPC) determination}

Before the TPC analysis, to individuate non-dormant seeds, two replicates of 50 seeds per genotype were put in petri dishes to begin their germination. As expected, after 10 days, only a few seeds were imbibed and began the germination process (i.e. the percentage of non-dormant seeds). Dormant (seed which did not imbibe and begin the germination process) and non-dormant seeds were dried at room temperature until they reached their initial weight (approximately the 10\% moisture as determined on a separate sample). Total polyphenols in seeds and in the hot water treatments (at 70 and $90{ }^{\circ} \mathrm{C}$ ) were determined according to Inácio et al. (2013). In detail, to analyse TPC, $5 \mathrm{mg}$ of the dried, grinded powder of dormant and non-dormant seeds was added with $3 \mathrm{~mL}$ of methanol: water $(1: 1, v / v)$ and heated to boiling point. To analyse TPC in the hot water solutions, 50 intact seeds were weighted and heated in $50 \mathrm{ml}$ water at $70{ }^{\circ} \mathrm{C}$ and $90{ }^{\circ} \mathrm{C}$. Subsequently, in both determinations, an aliquot $(500 \mu \mathrm{L})$ of the cooled and filtered extract was mixed with distilled water $(7 \mathrm{~mL})$ and Folin-Ciocalteau reagent $(500 \mu \mathrm{L})$ under constant stirring for $1 \mathrm{~min}$, following which saturated sodium carbonate solution $(1 \mathrm{~mL})$ was added to the mixture and the whole diluted to $10 \mathrm{~mL}$ with distilled water. After $30 \mathrm{~min}$ at room temperature, the absorbance of the mixture was determined at $730 \mathrm{~nm}$. A calibration curve using gallic acid in the range of $0-100 \mu \mathrm{g} \mathrm{mL}^{-1}$ as the reference standard was done to analyze TPC, expressed as $\mu \mathrm{g}$ of gallic acid equivalents per $\mathrm{mL}^{-1}$. TPC was then expressed in $\mathrm{mg}$ of gallic acid equivalents (GAE) per $\mathrm{g}$ of seed fresh weight (FW) by the following formula:

$y=\frac{a \times b}{c}$,

where: $a=\mathrm{mg}$ TPC per $\mathrm{mL}^{-1}, b=\mathrm{ml}$ of the solution diluting the sample, $c=$ fresh weight of the sample material used (i.e. $5 \mathrm{mg}$ for the intact dormant or non-dormant seeds or the weight of fifty seeds in the hot water treatments).

\section{Statistical analysis}

Total germination percentages, after arcsine transformation, and total polyphenols content were analysed by a randomized two-way analysis (main factors: genotypes and seed treatments) of variance (ANOVA) using COSTAT version 6.003 (cohort 3 Software). Data were arranged in a complete randomized experimental design with three replications. When the F test of the ANOVA was significant, treatment means were separated at $p \leq 0.05$ according to the Least Significant Difference (LSD) method (Snedecor and Cochran 1989). On the treatments achieving at least $50 \%$ germination, the time (hours) to $50 \%$ germination (t50) was calculated by a logistic equation with three parameters (SIGMAPLOT 11 software, Systat Software Inc., San Jose, California, USA):

$y=\frac{a}{1+\left(\frac{x}{x 0}\right)^{b}}$,

where $a$ is the maximum value of germination observed for each genotype, $x$ is the time after seed imbibition, expressed in hours, $x_{0}$ is the time (hours) to $50 \%$ seed germination, $b$ is a fitting parameter of the curve. The $x$ value on the curve, which corresponded to $50 \%$ germination, was assumed as theoretical time (t50) to $50 \%$ germination (Patanè et al. 2016). The confidence intervals of $t 50$ were calculated on the 95\% confidence bands of the logistic curve (SIGMAPLOT 11 software). 


\section{Results}

\section{Effects of hot water treatment on carob seed germination}

Overall seed germination of untreated seeds (control) ranged from 0\% (Margitello) to 13.3\% (Sorba and Pignato) (Table 3 ) and the only few seeds that germinated were the ones that were able to absorb water and swell i.e. the nondormant seeds in the seed lot. The remaining seeds did not swell during all the germination trial. Chemical scarification in sulphuric acid (96\%) determined a germination percentage ranging from 93.3 to $100.0 \%$ in all tested genotypes. Soaking in $70{ }^{\circ} \mathrm{C}$ water determined significant increases of germination over the control only in Sorba $(+20 \%$ points as compared to the $13.3 \%$ of the control). Seeds, which did not germinate, did not swell. Soaking in $90{ }^{\circ} \mathrm{C}$ hot water treatment always significantly improved seed germination as compared to the control, to a different extent depending on genotype. In particular, germination after seed treatment exceeded $90 \%$ in Sorba, TDP and Pignato, and 70\% in Margitello; seed treatment was less but still significantly effective in Calamiccio (47\% seed germination).

\section{Time course of germination and $\mathbf{t 5 0}$}

Time course of seed germination after $90{ }^{\circ} \mathrm{C}$ hot water treatment and sulphuric acid treatment well fitted to the logistic curve (Fig. 1). The curves relative to the germination after $70{ }^{\circ} \mathrm{C}$ hot water treatment and those for the
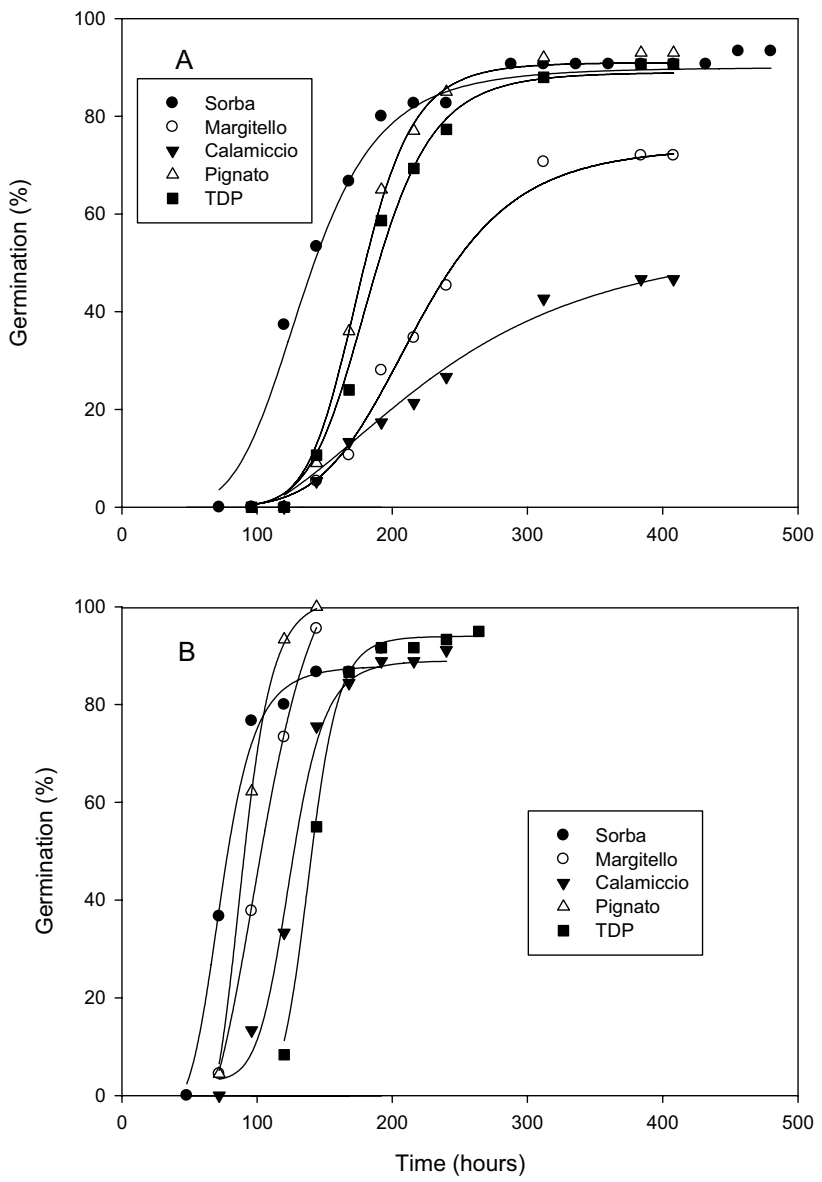

Fig. 1 Time course of seed germination after $90^{\circ} \mathrm{C}$ hot water treatment (A) and sulphuric acid treatment (B) fitted to the logistic curve

Table 3 Treatments effects on carob final seed germination (\%)

\begin{tabular}{|c|c|c|c|c|c|c|}
\hline Code & Control & Hot water $70{ }^{\circ} \mathrm{C}$ & & Hot water $90^{\circ} \mathrm{C}$ & Sulphuric acid & Overall means \\
\hline Sorba & $13.3(21.1) \mathrm{f}$ & $33.3(35.0) \mathrm{e}$ & & $93.3(75.6) b$ & $93.3(75.6) b$ & $58.3(51.7) \mathrm{A}$ \\
\hline TDP & $6.7(12.3) \mathrm{g}$ & $11.1(19.3) \mathrm{fg}$ & & 90.7 (72.6) b & $97.0(80.3) b$ & $51.4(46.1) \mathrm{B}$ \\
\hline Pignato & $13.3(21.1) \mathrm{f}$ & $23.3(28.9)$ ef & & 93.3 (75.6) b & $100.0(90.0) \mathrm{a}$ & $57.5(54.6) \mathrm{A}$ \\
\hline Margitello & $0.0(0.0) \mathrm{h}$ & $0.0(0.0) \mathrm{h}$ & & $72.0(58.3) \mathrm{c}$ & $95.0(79.5) b$ & 41.8 (34.5) C \\
\hline Calamiccio & $8.0(16.1) \mathrm{fg}$ & $0.0(0.0) \mathrm{h}$ & & $46.67(43.1) \mathrm{d}$ & $93.3(75.6) \mathrm{b}$ & 37.0 (33.6) C \\
\hline Overall means & $8.3(14.1) \mathrm{C}$ & $13.6(16.6) \mathrm{C}$ & & $79.2(65.7) \mathrm{B}$ & 95.7 (80.0) A & \\
\hline \multicolumn{5}{|l|}{ Anova } & \multicolumn{2}{|l|}{ LSD } \\
\hline Effect & SS & DF & MS & $F$ & $p \leq 0.05$ & $p \leq 0.01$ \\
\hline Genotype (G) & 4510.19 & 4 & \multicolumn{2}{|l|}{1127.55} & 4.20 & 5.61 \\
\hline Treatment (T) & $51,080.36$ & 3 & \multicolumn{2}{|l|}{$17,026.79$} & 3.75 & 5.02 \\
\hline $\mathrm{G} \times \mathrm{T}$ & 2594.31 & 12 & \multicolumn{2}{|l|}{216.19} & 8.09 & 11.23 \\
\hline Residual & 1034.28 & 40 & \multirow{2}{*}{\multicolumn{2}{|c|}{25.86}} & & \\
\hline Total & $59,219.14$ & 59 & & & & \\
\hline
\end{tabular}

Actual data are shown. In brackets arcsine transformed percentages (Bliss transformation) to be confronted by L.S.D

Different lowercase letters indicate significant difference for the interaction genotype $\times$ treatment at $p<0.05$. Different uppercase letters indicate significant difference among genotypes or treatments at $p<0.05$ 
control were not calculated since no genotype achieved $50 \%$ germination. Hot water $\left(90{ }^{\circ} \mathrm{C}\right.$ soaked seeds) and sulphuric acid treatments differently affected the time to $50 \%$ germination (t50) (Table 4).

Hot water $\left(90^{\circ} \mathrm{C}\right)$ determined significant differences among the genotypes: treated seeds of Sorba showed the lowest t50 (142.1 h), followed by those of TDP and Pignato $(188.6$ and $178.7 \mathrm{~h})$; the highest t50 values were observed in seeds of Margitello (250.8 h) and Calamiccio (468 h) (Table 4). Thus, with the exception of Pignato, the other two genotypes (Margitello and Calamiccio) grown in the driest environment (Ispica, Table 2) showed the longest t50. Sulphuric acid treatment determined significant decreases in t50 in all the tested genotypes as compared to hot water treatment. With the only exception of the TDP genotype, no significant differences were observed in the time to $50 \%$ germination of the other genotypes induced by the acid treatment (Table 4).

\section{Total polyphenols in dormant, non-dormant seeds and leached in the hot water treatments}

Total polyphenol content (TPC) in dormant seeds (Table 5) was significantly influenced by the genotype. The highest values were observed in the genotypes Margitello (46.0 $\mathrm{mg} \mathrm{g}^{-1}$ of seed FW) and Calamiccio (39.3 $\mathrm{mg} \mathrm{g}^{-1}$ of seed FW), the other genotypes showed lower undifferentiated values (on average $29.5 \mathrm{mg} \mathrm{g}^{-1}$ of seed FW).

As compared to dormant seeds, non-dormant ones (i.e. the few seeds which imbibed and germinated without any treatment) showed an almost halved TPC (on average 17.0 as compared to $34.8 \mathrm{mg} \mathrm{g}^{-1}$ of seed FW of the dormant ones). The lowest content was detected in the Sorba genotype (12.8 $\mathrm{mg} \mathrm{g}^{-1}$ of seed FW), the highest in the Calamiccio genotype (20.9 $\mathrm{mg} \mathrm{g}^{-1}$ of seed $\mathrm{FW}$ ).

As concerns the polyphenols leached in water after warm water treatments, total polyphenols leaching at $70{ }^{\circ} \mathrm{C}$ in the different genotypes showed a narrow range of variation ranging from 0.211 to $0.289 \mathrm{mg} \mathrm{g}^{-1} \mathrm{FW}$ of the seeds for TDP and Sorba genotype, respectively (Table 6).
Table 4 Treatments effect on the 50 (hours) from the logistic regression (20 days from the germination beginning)

\begin{tabular}{lllrrr}
\hline Code & $90{ }^{\circ} \mathrm{C}$ hot water & $\begin{array}{l}\text { 95\% Confidence } \\
\text { intervals }\end{array}$ & $\begin{array}{l}\text { Sulphuric } \\
\text { acid (SA) }\end{array}$ & $\begin{array}{l}\text { 95\% Confidence } \\
\text { intervals }\end{array}$ & $\begin{array}{l}\text { t50 reduction } \\
\text { determined by } \\
\text { SA }\end{array}$ \\
\hline Sorba & 142.1 & $135.8-149.0$ & 84.0 & $82.9-121.8$ & -64.0 \\
TDP & 188.6 & $182.5-194.7$ & 141.8 & $140.6-142.9$ & -49.9 \\
Pignato & 178.7 & $175.5-181.9$ & 91.1 & $76.1-103.5$ & -88.9 \\
Margitello & 250.8 & $237.4-267.8$ & 102.8 & $79.1-126.7$ & -144.7 \\
Calamiccio & 468.0 & $394.3-499.2$ & 127.1 & $121.9-133.7$ & -274.0 \\
\hline
\end{tabular}

Table 5 Total polyphenols ( $\mathrm{mg} \mathrm{g}^{-1}$ of seed FW) in dormant or non-dormant seeds

\begin{tabular}{|c|c|c|c|c|c|c|}
\hline \multicolumn{2}{|l|}{ Genotype } & \multicolumn{2}{|l|}{ Dormant seeds } & \multicolumn{2}{|l|}{ Non-dormant seeds } & Overall means \\
\hline Sorba & & $26.7 \mathrm{bc}$ & & $12.8 \mathrm{~d}$ & & $19.65 \mathrm{~B}$ \\
\hline TDP & & $31.3 \mathrm{~b}$ & & $16.3 \mathrm{~cd}$ & & $23.83 \mathrm{~B}$ \\
\hline Pignato & & $30.6 \mathrm{~b}$ & & $20.5 \mathrm{c}$ & & $25.58 \mathrm{AB}$ \\
\hline Margitello & & $46.0 \mathrm{a}$ & & $14.6 \mathrm{~cd}$ & & $30.30 \mathrm{~A}$ \\
\hline Calamiccio & & $39.3 \mathrm{a}$ & & $20.9 \mathrm{c}$ & & $30.13 \mathrm{~A}$ \\
\hline Overall means & & $34.80 \mathrm{~A}$ & & $17.02 \mathrm{~B}$ & & \\
\hline \multirow[t]{2}{*}{ Effect } & \multicolumn{4}{|l|}{ Anova } & \multicolumn{2}{|l|}{ LSD } \\
\hline & SS & DF & MS & $F$ & $p \leq 0.05$ & $p \leq 0.01$ \\
\hline Genotype (G) & 322.54 & 4 & 80.64 & $6.86^{* *}$ & 5.40 & 7.68 \\
\hline Dormancy (D) & 1584.39 & 1 & 1584.39 & $134.7 * *$ & 3.42 & 4.86 \\
\hline $\mathrm{G} \times \mathrm{D}$ & 264.25 & 4 & 66.06 & $5.62 *$ & 7.64 & 10.87 \\
\hline Residual & 117.58 & 10 & 11.76 & & & \\
\hline Total & 2288.76 & 19 & & & & \\
\hline
\end{tabular}

Different lowercase letters indicate a significant difference for the interaction genotype $\times$ dormancy at $p<0.05$. Different uppercase letters indicate significant difference among genotypes or between dormancy at $p<0.05$ 
Table 6 Total leached polyphenols ( $\mathrm{mg} \mathrm{g}^{-1}$ of seed FW) in relation to the hot water treatments

\begin{tabular}{|c|c|c|c|c|c|c|}
\hline \multicolumn{2}{|l|}{ Genotype } & \multicolumn{2}{|l|}{ Hot water $\left(70^{\circ} \mathrm{C}\right)$} & \multicolumn{2}{|l|}{ Hot water $\left(90^{\circ} \mathrm{C}\right)$} & Overall means \\
\hline Sorba & & $0.289 \mathrm{~b}$ & & $0.402 \mathrm{a}$ & & $0.345 \mathrm{~A}$ \\
\hline TDP & & $0.211 \mathrm{c}$ & & $0.276 \mathrm{~b}$ & & $0.243 \mathrm{C}$ \\
\hline Pignato & & $0.213 \mathrm{c}$ & & $0.282 \mathrm{~b}$ & & $0.248 \mathrm{C}$ \\
\hline Margitello & & $0.223 \mathrm{c}$ & & $0.296 \mathrm{~b}$ & & $0.259 \mathrm{~B}$ \\
\hline Calamiccio & & $0.212 \mathrm{c}$ & & $0.379 \mathrm{a}$ & & $0.295 \mathrm{~b}$ \\
\hline Overall means & & $0.230 \mathrm{~B}$ & & $0.327 \mathrm{~A}$ & & \\
\hline \multirow[t]{2}{*}{ Effect } & \multicolumn{4}{|l|}{ Anova } & \multicolumn{2}{|l|}{ LSD } \\
\hline & SS & DF & MS & $F$ & $p \leq 0.05$ & $p \leq 0.01$ \\
\hline Genotype (G) & 0.029 & 4 & 0.007 & $38.262 * *$ & 0.022 & 0.031 \\
\hline Water temp. (T) & 0.047 & 1 & 0.047 & $249.455^{* *}$ & 0.014 & 0.020 \\
\hline $\mathrm{G}^{\times} \mathrm{T}$ & 0.008 & 4 & 0.002 & $9.875^{* *}$ & 0.031 & 0.044 \\
\hline Residual & 0.002 & 10 & 0.000 & & & \\
\hline Total & 0.086 & 19 & & & & \\
\hline
\end{tabular}

Different lowercase letters indicate significant difference for the interaction genotype $\times$ water temperature at $p<0.05$. Different uppercase letters indicate significant difference among genotypes or water temperature at $p<0.05$

In all the tested genotypes, the $90{ }^{\circ} \mathrm{C}$ hot water treatment determined significant higher values of total leached polyphenol. The highest leaching values were observed in Calamiccio ( $0.379 \mathrm{mg} \mathrm{g}^{-1} \mathrm{FW}$ of the seeds) and Sorba (0.402 $\mathrm{mg} \mathrm{g}^{-1} \mathrm{FW}$ of the seeds).

When the data of the total polyphenols leached during the two hot water treatments were plotted against the germination percentages, a significant $(p \leq 0.01)$ correlation coefficient $\left(0.75^{* *}\right)$ resulted and the data well fitted $\left(R^{2}=0.56\right)$ to linear regression (Fig. 2) showing that germination rises as polyphenols leaching increases in the hot water solution.

\section{Discussion}

Intact seeds from the studied carob genotypes showed an erratic, scarce or null germination (from 0 to 20\%) when germinated in distilled water, confirming that seed dormancy affects this species (Pérez-García 2009) similarly to other Fabaceae taxa. These germinated seeds (non-dormant) are the only ones that imbibe and probably germinate shortly after their dispersion. Notwithstanding the ancient domestication, this long-living species has, therefore, maintained this ancestral wild trait (Gunes et al. 2013), which makes it necessary to scarify the seed to permit germination. In natural environments, several factors (mechanical friction
Fig. 2 Total seed polyphenols leached in the two warm water treatments versus germination

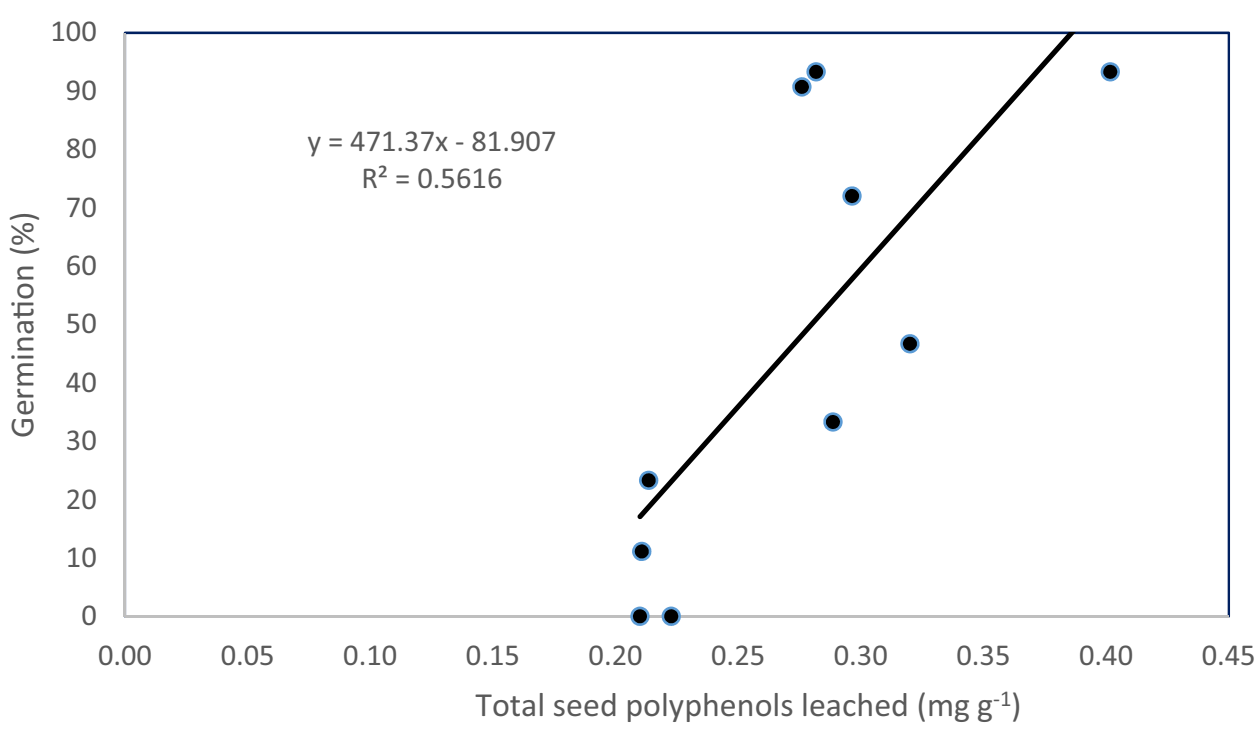


determined by soil particles, microbial action, passage through the digestive system of mammals, etc.) alter seed coats (Pérez-García 2009), scattering germination over time and ensuring species survival. However, a rapid and uniform germination may be useful to promote the nursery activity for this important species.

Our results confirm that carob seeds gave the highest percentage of germination after $96 \%$ sulphuric acid treatment for 20 min (Zaen El Deen et al. 2014) and in a shorter time as compared to hot water treatment. The almost complete germination obtained in all genotypes confirms that their embryos are ready to germinate, and that dormancy overcoming determined by the acid is associated to the almost complete disruption of the hard seed coat.

In our study, hot water soaking was effective in enhancing germination but evidenced a larger variability in the germination response among genotypes. Moreover, its effectiveness is strictly dependent on the soaking temperature. The most successful treatment was that at $90{ }^{\circ} \mathrm{C}$ since at a lower temperature $\left(70{ }^{\circ} \mathrm{C}\right)$ the treatment was almost ineffective. Some considerations seem to arise from our results. The permeability of seed coat and thus dormancy in the Fabaceae, are generally attributed to the hardness of the seed coat mainly tied to the palisade layer, formed by cells with strongly thickened walls, located next to each other with no gaps between them. However, Van Staden et al. (1989) suggested that the water-impermeable substances located in the outer ends of the palisade layer are responsible for the resistance to water entry inside the legume seeds (Rolston 1978). Lignin has been recognized as present in the epidermal palisade-like cells and is usually designated as the main responsible of seed coat permeability (Serrato-Valenti et al. 1995; Baskin and Baskin 2004; Ma et al. 2004). According to Kelly et al. (1992), differences in the lignification of palisade-like cells may determine either the permeability or the non-permeability to the water of the seeds. Baskin et al. (2000) suggested that the presence of a palisade-like cell layer in the seed coat, even if lignified, does not necessarily determine seed waterproofness since it is also important how compacted the palisade-like cells are. However, lignin impregnating the palisade coat is an insoluble polymer in water and in acid, only soluble in strong concentrated basis or recently by base-catalysed steam treatments (Lavoie et al. 2011). It is not digested or absorbed, nor attacked by colonic microflora. Furthermore, it is well known that cellulose, another important structural component of the seed coat, is insoluble in water and in common organic solvents and is slowly attacked by boiling with diluted mineral acids, such as hydrochloric or sulphuric acid or by autoclaving at $140-170{ }^{\circ} \mathrm{C}$. Thus, the most important structural components of the seed coat are not soluble in the most effective hot temperature $\left(90^{\circ} \mathrm{C}\right)$ used in our experiments. However, the thickness of the cell wall, and the compacted organization of these layers determine a solid structure of the seed coat, which may have a protective mechanical function (Orozco-Segovia et al. 2007). Therefore, other compounds that are removed by hot water treatments may be responsible for carob seed dormancy. Phenols have also been recognized as components of the Fabaceae seed coats (Rolston 1978; Rangaswamy and Nandakumar 1985; Werker 1997). The present study, for the first time, demonstrated that total polyphenols leaching during hot water treatment is correlated to the beginning of the seed imbibition and thus to seed germination in carob. These results and the considerations regarding the seed coat constituents seem to indicate that dormancy in this species is not only associated with seed coat hardness, as it has been considered in the past, but also with total polyphenols removal from the seed coat. Another indirect confirmation of their role in carob seed dormancy results from the examination of their content in dormant and non-dormant seeds of each analysed genotype. TPC in dormant seeds, in fact, resulted almost double that of the non-dormant seeds. Phenolic acids (caffeic, ferulic and cinnamic acids), phenolic substances such as tannins, flavonols (quercetin), are known to inhibit seed germination in Palicourea rigida (Inácio et al. 2013) and Sorghum bicolor (Patanè et al. 2008). In the first species, phenolic compounds in seeds have been indicated as the main responsible of the physiological dormancy and seems to exert a protective function since total phenolic content increases soon after seed dispersal and degrades over time (Inácio et al. 2013).

The inhibitory effects of phenolic compounds on seed germination are still debated (Bewley et al. 2013), they have been considered strictly associated to the regulation of seed coat permeability, and oxygen supply to embryos (Willemsen and Rice 1972; Bewley and Black 1994). Water-soluble phenolic compounds reduce germination by inhibiting the activities of peroxidases and the oxidation of other phenolics, processes that are indispensable for breaking the hard seed coat and promote the emergence of the seedling in Triticum aestivum (Kong et al. 2008). Moreover, the low t50 differences among the genotypes after sulphuric acid-treatment (Table 4), confirm that acid treatment destroys the structure of the seed coat, thus allowing water imbibition (Nikolaeva 1977; Aliero 2004) and a uniform germination whatever the hardiness of the seed coat.

On the opposite, the relevant differences in the t50 observed among the five genotypes after the most effective hot water treatment seem to indicate that after the imbibition, in some of them (i.e. the two genotypes with the longer t50, Calamiccio and Margitello), the embryo has to overcome a harder seed coat. It is noticeable these two genotypes showed also the highest TPC in their seeds.

After water penetration determined by hot water treatment, seeds still have to overcome the hardness of the 
seed coat (see longer 50 s of hot water treated seeds as compared to acid-treated ones), and the expansion force may be represented by the imbibition of the galactomannans, the main components of the well-known valuable carob bean gum. In fact, hydrophilic galactomannans are the main components of the endosperm walls in carob (McCleary and Matheson 1974) and they come to be mucilaginous after a period of imbibition (Reid and Bewley 1979). In the study of Cavallaro et al. (2016), a $120 \%$ increase in seed weight was determined after $72 \mathrm{~h}$ from the beginning of imbibition. An indirect confirmation of the role of galactomannans in the rupture of the hard testa may be a study carried out by Gong et al. (2005). They demonstrated that, in carob, there is a low activity of endo-b-mannanase (the enzyme liable for galactomannans demolition) in the endosperm and thus a low demolition rate of the galactomannans during the first phases of seed germination and that the enzyme activity increases only after the radicle emergence from the seed. Diffusible saponin-like substances, also present in carob endosperm, strongly inhibit any increase in a beta-mannanase activity. Based on our observation, we suggest that, after water entry in the seed, since galactomannans have a higher imbibition capability, their depletion must be inhibited to permit them to imbibe and to determine a pressure able to break the still hard seed coat. These important compounds of carob endosperm, perhaps, play also an important ecological role in determining the genotypes tolerance to water stress (Cavallaro et al. 2016). Spyropoulos and Lambiris (1980) seem to confirm this hypothesis, since they observed that plantlet growth is strictly related to galactomannan reduction, the latter being inhibited by lower external water potential. After germination is completed, these compounds may be demolished and act like food reserves to support the earliest phases of plantlet growth as in other species like lettuce, tomato and Datura whose endosperm cells have thick cell walls abundant in mannan-based polymers (Gong et al. 2005).

This study also confirmed the existence of considerable diversity in the toughness of the seed coat (different degrees of physical dormancy) even within genotypes growing in a restricted geographic area (Pérez-García 2009; Cavallaro et al. 2016). It was demonstrated that in Scorpiurus, an herbaceous wild legume species, and in other legumes, the genotypes coming from drier climates showed a higher quantity of hard seeds compared to those coming from a rainier climate (Gresta et al. 2007). These observations result in more difficulty in centenarian carob trees as the genotypes collected in Sicily. However, from the examination of the 30-years meteorological data, with the only exception of Pignato, the genotypes coming from the drier environment (Ispica) showed a harder seed coat and a higher TPC in their seeds.

\section{Conclusions}

In the present study, the effects of different scarification treatments and the role of carob seed polyphenols on germination of five carob genotypes collected in Sicily (Italy) were discussed. Sulphuric acid and hot water treatments were very effective in improving carob seed germination. However, the effectiveness of the latter treatment is linked to the $90{ }^{\circ} \mathrm{C}$ temperature, which led to the removal of the highest amount of polyphenols from the seed coat without damaging the embryo. The high correlation between the polyphenols removed from the seed coat and germination after hot water soaking, the lower total polyphenol content of non-dormant seeds suggests that dormancy in this species is not only associated with seed coat hardness, but also to TPC in the seeds. Further studies may determine the polyphenols involved, but also assess new, easier to carry out, seed treatments to improve seed germination of this Mediterranean tree with a high ecological value. Finally, similar studies may contribute to improve the knowledge of dormancy processes in other Fabaceae species whose germination is positively affected by hot water treatments.

Author contribution statement Conceptualization, VC; Methodology, VC; Formal analysis, CM and CP; Investigation, VC; Resources, CM and GF; Data curation, AP; Writing-original draft preparation, VC; Writing—review and editing, CM, CP, GF, AP and ACB; Supervision, VC and ACB.

Acknowledgements The authors wish to thank Mrs. Irene Longo and Mr. Salvatore La Rosa for their technical assistance.

Funding Open access funding provided by Università degli Studi di Padova within the CRUI-CARE Agreement.

Open Access This article is licensed under a Creative Commons Attribution 4.0 International License, which permits use, sharing, adaptation, distribution and reproduction in any medium or format, as long as you give appropriate credit to the original author(s) and the source, provide a link to the Creative Commons licence, and indicate if changes were made. The images or other third party material in this article are included in the article's Creative Commons licence, unless indicated otherwise in a credit line to the material. If material is not included in the article's Creative Commons licence and your intended use is not permitted by statutory regulation or exceeds the permitted use, you will need to obtain permission directly from the copyright holder. To view a copy of this licence, visit http://creativecommons.org/licenses/by/4.0/.

\section{References}

Aliero BL (2004) Effects of sulphuric acid, mechanical scarification and wet heat treatments on germination of seeds of African 
locust bean tree Parkia biglobosa. Afr J Biotechnol 3:179-181. https://doi.org/10.5897/ajb2004.000-2031

Amessis-Ouchemoukh N, Ouchemoukh S, Meziant N, Idiri Y, Hernanz D, Stinco CM, Rodríguez-Pulido FJ, Heredia FJ, Madani $\mathrm{K}$, Luis J (2017) Bioactive metabolites involved in the antioxidant, anticancer and anticalpain activities of Ficus carica L., Ceratonia siliqua L. and Quercus ilex L. extracts. Ind Crop Prod 95:6-17. https://doi.org/10.1016/j.indcrop.2016.10.007

Baskin JM, Baskin CC (2004) A classification system for seed dormancy. Seed Sci Res 14:1-16. https://doi.org/10.1079/ssr20 03150

Baskin C, Baskin JM (2014) Seeds: ecology, biogeography, and evolution of dormancy and germination. Academic Press, San Diego, $p$ 1600. https://doi.org/10.1016/C2013-0-00597-X

Baskin JM, Baskin CC, Li X (2000) Taxonomy, anatomy and evolution of physical dormancy in seeds. Plant Spec Biol 15:139-152. https://doi.org/10.1046/j.1442-1984.2000.00034.x

Benković M, Belščak-Cvitanović A, Bauman I, Dr K, Srečec S (2017) Flow properties and chemical composition of carob (Ceratonia siliqua L.) flours as related to particle size and seed presence. Food Res Int 100:211-218. https://doi.org/10.1016/j.foodres. 2017.08.048

Bewley JD, Black M (1994) Seeds. Physiology of development and germination, 2nd edn. Plenum Press, New York. https://doi.org/ 10.1007/978-1-4899-1002-8

Bewley JD, Bradford KJ, Hilhorst HWM., Nonogaki H (2013) Dormancy and the Control of Germination. In: Seeds. Springer, New York, NY. https://biblioproxy.cnr.it:2481/10.1007/ 978-1-4614-4693-4_6.

Bianco CA, Kraus TA (2005) Desarrollo y estructura de la semilla y el fruto de Adesmia bicolor (Poir.) DC. (Fabaceae). Phyton 54:71-77

Brosche V (2017) Das Oleo Ceratonion. Universität Hohenheim, Stuttgart

Cartabellotta D, Drago A, Lo Bianco B, Lombardo M (1998) Climatologia della Sicilia. Regione Siciliana, Assessorato Agricoltura e Foreste, Palermo

Cavallaro V, Barbera A, Maucieri C, Gimma G, Scalisi C, Patanè C (2016) Evaluation of variability to drought and saline stress through the germination of different ecotypes of carob (Ceratonia siliqua L.) using a hydrotime model. Ecol Eng 95:557-566. https://doi.org/10.1016/j.ecoleng.2016.06.040

Forbes I, Wells HD (1968) Hard and soft seededness in blue lupine, Lupinus angustifolius L., inheritance and phenotype classification. Crop Sci 8:195-197. https://doi.org/10.2135/cropsci1968.00111 83X000800020018x

Gong X, Bassel GW, Wang A, Greenwood JS, Bewley D (2005) The emergence of embryos from hard seeds is related to the structure of the cell walls of the micropylar endosperm, and not to endo-bmannanase activity. Ann Bot 96:1165-1173. https://doi.org/10. 1093/aob/mci269

Gresta F, Avola G, Abbate V (2007) Germination ecology of Scorpiurus subvillosus $\mathrm{L}$. seeds, the role of temperature and storage time. Plant Ecol 190:123-130. https://doi.org/10.1007/ s11258-006-9195-3

Gresta F, Avola G, Onofri A, Anastasi U, Cristaudo A (2011) When does hard coat impose dormancy in legume seeds? Lotus and Scorpiurus case study. Crop Sci 51:1-9. https://doi.org/10.2135/ cropsci2010.12.0700

Gubbuk H, Kafkas E, Guven D, Gunes E (2010) Physical and phytochemical profile of wild and domesticated carob. Span J Agric Res 8:1129-1136. https://doi.org/10.5424/sjar/2010084-1209

Gunes E, Gubbuk H, Ayala-Silva T, Gozlekci S, Ercisli S (2013) Effects of various treatments on seed germination and growth of carob (Ceratonia siliqua L.). Pak J Bot 45:1173-1177
Hosseini SM, Savadkoohi SK, Ahmadi E (2013) Effect of different seed treatments on dormancy breaking and germination in three species in arid and semi-arid lands. For Sci Pract 15:130-136. https://doi. org/10.1007/s11632-013-0209-7

Inácio MC, Moraes RM, Mendonça PC, Morel LJF, França SC, Bertoni BW, Pereira AMS (2013) Phenolic compounds influence seed dormancy of Palicourea rigida H.B.K. (Rubiaceae), a medicinal plant of the brazilian savannah. Am J Plant Sci 4:129-133. https:// doi.org/10.4236/ajps.2013.41017

Janick J, Paull RE (2008) The encyclopedia of fruit and nuts. CABI Publishing, Wallingford, p 900. https://doi.org/10.1079/97808 51996387.0000

Kelly KM, Van Staden J, Bell WE (1992) Seed coat and dormancy. Plant Growth Regul 11:201-209. https://doi.org/10.1007/BF000 24559

Kilen TC, Hartwig EE (1978) An inheritance study of impermeable seed in soybeans. Field Crop Res 1:65-70. https://doi.org/10. 1016/0378-4290(78)90007-2

Kong L, Wang F, Si J, Feng B, Li S (2008) Water-soluble phenolic compounds in the coat control germination and peroxidase reactivation in Triticum aestivum seeds. Plant Growth Regul 56(3):275283. https://doi.org/10.1007/s10725-008-9307-2

Lahijanian S, Nazari M (2017) Increasing germination speed of common bean (Phaseolus vulgaris L.) seeds by ultrasound treatments. Seed Technol 38:49-55

Lavoie JM, Barè W, Bilodeau M (2011) Depolymerization of steamtreated lignin for the production of green chemicals. Bioresour Technol 102:4917-4920. https://doi.org/10.1016/j.biortech.2011. 01.010

Ma F, Cholewa E, Mohamed T, Peterson CA, Gijzen M (2004) Cracks in the palisade cuticle of soybean seed coats correlate with their permeability to water. Ann Bot 94:213-228. https://doi.org/10. 1093/aob/mch133

Mackay WA, Davis TD, Sankhla D (1995) Influence of scarification and temperature treatments on seed germination of Lupinus havardii. SST 23:815-821

Mazaheri D, Shojaosadati SA, Mousavi SM, Hejazi P, Saharkhiz S (2012) Bioethanol production from carob pods by solid-state fermentation with Zymomonas mobilis. Appl Energy 99:372-378. https://doi.org/10.1016/j.apenergy.2012.05.045

McCleary BV, Matheson NK (1974) $\alpha$-D-Galactosidase activity and galactomannan and galactosylsucrose oligosaccharide depletion in germinating legume seeds. Phytochemistry 13:1747-1757. https:// doi.org/10.1016/0031-9422(74)85084-3

Nikolaeva MG (1977) Factors controlling the seed dormancy pattern. In: Khan AA (ed) The physiology and biochemistry of seed dormancy and germination. North-Holland Publishing Company, Amsterdam, pp 51-74

Orozco-Segovia A, Márquez-Guzmán J, Sánchez-Coronado ME, Gamboa de Buen A, Baskin JM, Baskin CC (2007) Seed anatomy and water uptake in relation to seed dormancy in Opuntia tomentosa (Cactaceae, Opuntioideae). Ann Bot 99:581-592. https://doi.org/ 10.1093/aob/mcm001

Ortiz PL, Arista M, Talavera S (1995) Germination ecology of Ceratonia siliqua L. (Cesalpinaceae), a Mediterranean tree. Flora 190:89-95. https://doi.org/10.1016/S0367-2530(17)30630-8

Patanè C, Cavallaro V, D'Agosta G, Cosentino SL (2008) Plant emergence of PEG-osmoprimed seeds under suboptimal temperatures in two cultivars of sweet sorghum differing in seed tannin content. J Agron Crop Sci 194:304-309. https://doi.org/10.1111/j.1439037X.2008.00314.X

Patanè C, Saita A, Tubeileh A, Cosentino SL, Cavallaro V (2016) Modeling seed germination of unprimed and primed seeds of sweet sorghum under PEG-induced water stress through the hydrotime analysis. Acta Physiol Plant 38:115. https://doi.org/10.1007/ s11738-016-2135-5 
Pérez-García F (2009) Germination characteristics and intra-population variation in carob (Ceratonia siliqua L.) seeds. Span J Agric Res 7:398-406. https://doi.org/10.5424/sjar/2009072-431

Piotto B, Di Noi A (2003) Seed Propagation of Mediterranean Trees and Shrubs. Agency for the Protection of the Environment and for Technical Services (APAT), Rome, Italy, pp 108

Rangaswamy NS, Nandakumar L (1985) Correlative studies on seed coat structure, chemical composition, and impermeability in the legume Rhynchosia minima. Bot Gaz 146:501-509. https://doi. org $/ 10.1086 / 337555$

Reid JSG, Bewley JD (1979) A dual role for the endosperm and its galactomannan reserves in the germinative physiology of fenugreek (Trigonella foenum-graecum L.), an endospermic leguminous seed. Planta 147:145-150. https://doi.org/10.1007/BF003 89515

Rifna E, Ramanan KR, Mahendran R (2019) Emerging technology applications for improving seed germination. Trends Food Sci Technol 86:95-108. https://doi.org/10.1016/j.tifs.2019.02.029

Rolston MP (1978) Water impermeable seed dormancy. Bot Rev 44:365-396. https://doi.org/10.1007/BF02957854

Serrato-Valenti G, De Vries M, Conaro L (1995) The hilar region in Leucaena leucocephala Lam. (De Wit) seed, Structure, histochemistry and the role of the lens in germination. Ann Bot 75:569-574. https://doi.org/10.1006/anbo.1995.1060

Silveira FAO, Fernandes GW (2006) Effect of light, temperature and scarification on the germination of Mimosa foliolosa (Leguminosae) seeds. SST 34:585-592. https://doi.org/10.15258/sst.2006. 34.3.05

Singleton VL, Rossi JA (1965) Colorimetry of total phenolics with phosphomolybdic-phosphotungstic acid reagents. Am J Enol Viticult 16:144-158

Snedecor GW, Cochran WG (1989) Statistical methods, 8th edn. Iowa State University Press, Ames

Spyropoulos CG, Lambiris MP (1980) Effect of water stress on germination and reserve carbohydrate metabolism in germinating seeds of Ceratonia siliqua L. J Exp Bot 31:851-857. https://doi.org/10. 1093/jxb/31.3.851

Van Staden J, Manning JC, Kelly KM (1989) Legume seeds - the structure: function equation. In: Stirton CH and Zarucchi JL (eds) Advances in legume biology. Monogr Syst Bot Missouri Bot Garden 29:417-450

Toscano S, Romano D, Tribulato A, Cavallaro V (2017) Assessing and modeling seed germination of Mediterranean wildflowers for low input landscape restoration. Restor Ecol 26:525-536. https://doi. org/10.1111/rec. 12608

Tsakaldimi M, Ganatsas P (2001) Treatments improving seeds germination of two Mediterranean sclerophyll species Ceratonia sili$q u a$ and Pistacia lentiscus. In: Proceedings of the Third Balkan Scientific Conference on Study, Conservation and Utilization of Forest Resources, Sofia, Bulgaria, Vol. II

Venier P, Funes G, Garcia CC (2012) Physical dormancy and histological features of seeds of five Acacia species (Fabaceae) from xerophytic forests in central Argentina. Flora 207:39-46. https:// doi.org/10.1016/j.flora.2011.07.017

Werker E (1997) Seed anatomy. In: Encyclopedia of Plant Anatomy. Gebrüder Borntraeger, Stuttgart Germany

Willemsen RW, Rice EL (1972) Mechanism of Seed Dormancy in Ambrosia artemisiifolia. Am J Bot 59:248-257. https://doi.org/ 10.1002/j.1537-2197.1972.tb10089.x

Zaen El Deen EM, El-Sayed OM, El-Sayed AEI, Hegazi GAE (2014) Studies on carob (Ceratonia siliqua L.) propagation. IOSR-JAVS 7:31-40. https://doi.org/10.9790/2380-07523140

Publisher's Note Springer Nature remains neutral with regard to jurisdictional claims in published maps and institutional affiliations. 